\title{
TERAJU
}

Teraju: Jurnal Syariah dan Hukum

Volume 01 Nomor 02, September 2019

DOI: $10.35961 /$ teraju.v1i02.93

\section{Pelarangan Riba dan Bunga Dalam Sistem Hukum Kontrak Syariah}

\author{
Sudanto \\ STAIN Sultan Abdurrahman Kepulauan Riau \\ sudanto@stainkepri.ac.id
}

\begin{abstract}
Abstrak

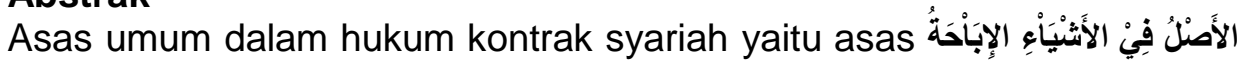
yang menyatakan bahwa segala sesuatu itu hukumnya boleh, kecuali ada dalil yang melarangnya. Selain itu, terdapat pula beberapa asas penting, yang satu dengan lainnya saling berkaitan, yaitu: asas konsensualisme, asas kekuatan mengikatnya kontrak dan asas kebebasan berkontrak. Implikasi dari asas-asas tersebut jika tidak dibatasi dengan ketentuan maupun perundangan-undangan akan mengakibatkan hilangnya ruh dari hukum kontrak syariah. Sehingga tulisan ini mencoba memaparkan pelarangan riba dan bunga dalam sistem hukum kontrak syariah sebagai bentuk upaya menjaga agar tidak kehilangan ruhnya.
\end{abstract}

Kata Kunci: Riba, Bunga, Hukum Kontrak Syariah.

\begin{abstract}
Abstrac
The general principle in sharia contract law is the principle of

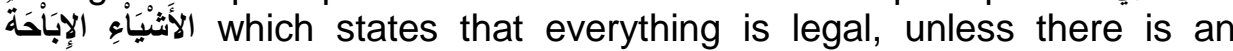
argument that prohibits it. In addition, there are also several important principles, which are interrelated to one another, namely: the principle of consensualism, the principle of the strength of contract binding and the principle of freedom of contract. The implications of these principles if not limited to the provisions or laws and regulations will result in the loss of the spirit of sharia contract law. So this paper tries to explain the prohibition of usury and interest in the legal system of sharia contracts as a form of efforts to keep it from losing its spirit.
\end{abstract}

Keywords: Usury, Interest, legal of sharia contracts. 


\section{Pendahuluan}

Islam adalah agama yang sempurna. Kesempurnaan tersebut dapat dilihat dengan adanya tuntunan dan tatanan hukum yang mengatur kehidupan manusia secara lengkap dan menyeluruh. Hukum Islam merupakan salah satu ajaran pokok umat yang berkenaan dengan tingkah laku manusia yang bersumber dari Al-Qur'an dan as-Sunnah. Artinya bahwa hukum Islam itu memperlihatkan urusan masyarakat yang berkaitan dengan ibadah, muamalat dan seluruh hukumnya. Hubungan manusia dengan Sang Khaliq diatur dalam bidang ibadah, sementara hal-hal yang berhubungan dengan sesama manusia diatur dalam bidang muamalat. Cakupan hukum muamalat sangatlah luas dan bervariasi, baik yang bersifat perorangan maupun yang bersifat umum, seperti perkawinan, kontrak atau perikatan, hukum pidana,peradilan dan sebagainya. ${ }^{1}$

Kontrak sebagai salah satu cakupan bidang muamalat eksistensinya bernilai urgen bagi kehidupan manusia karena dapat memfasilitasi pemenuhan kebutuhan hidup dan kepentingan manusia yang tidak mampu dipenuhi sendiri tanpa bantuan orang lain. Aturan main dalam pemenuhan kebutuhan dengan melibatkan orang lain haruslah jelas dan dewasa ini perlu dituangkan dalam suatu kontrak yang dapat melindungi kepentingan masingmasing pihak. ${ }^{2}$

Salah satu aplikasi kontrak tertuang dalam lini ekonomi, sebagaimana kita ketahui perekonomian seakan menjadi nyawa bagi setiap manusia, masyarakat, bangsa dan negara. Disadari atau tidak bahwa setiap manusia di dunia ini tidak akan bisa lepas dari yang namanya dunia

${ }^{1}$ Ghufron A. Mas'adi, Fiqh Muamalah Kontekstual, (Jakarta : PT. Raja Grafindo Persada, 2002), hlm. V.

${ }^{2}$ Nurjihad, Jurnal Hukum IUS QUIA IUSTUM NO. 3 VOL. 20 JULI 2013, hlm. 441. perekonomian karena hal ini merupakan salah satu fitrah manusia dalam menjalani kehidupannya, salah satu dari kegiatan perekonomian tersebut adalah bisnis. ${ }^{3}$

Dewasa ini bisnis syari'ah perkembangannya terus meningkat, dibuktikan makin banyak dan besarnya lembaga keuangan syariah perbankan maupun non bank, telah menuntut penggunaan atau implementasi akad (kontrak) syari'ah yang mampu memenuhi kepentingan para pihak/pelaku bisnis. Perbedaan utama kontrak konvensional dengan kontrak syariah adalah penerapan prinsip hukum Islam (syariah) dalam isi kontraknya. Perkembangan hukum kontrak syari'ah dewasa ini semakin mendapatkan tempat dan perhatian, seiring dengan perkembangan perekonomian syari'ah. ${ }^{4}$

Dalam kontrak syari'ah, selain mengacu pada asas umum dalam hukum Islam (muamalat) yaitu asas الأَصْنُ فِيْ الأَثَيْيَاِعِ الإِبَحَةُ sesuatu itu hukumnya boleh, kecuali ada dalil yang melarangnya, terdapat pula beberapa asas penting yang satu dengan lainnya saling berkaitan, yaitu: asas konsensualisme (the principle of consensualism, mabda' ar-Radhai'iyah), asas kekuatan mengikatnya kontrak (the principle of the binding force of contract) dan asas kebebasan berkontrak (the principle of freedom of contract, mabda' burriyyah at-Ta'aqud). ${ }^{5}$

3 Johan Arifin, Etika Bisnis Islami, (Semarang: Walisongo Press, 2009), hlm. 31.

${ }^{4}$ Nurjihad, Jurnal Hukum IUS QUIA

IUSTUM NO. 3 VOL. 20 JULI 2013, hlm. 441.

5 Ridwan Khairandy, "Landasan Filosofis Kekuatan Mengikatnya Kontrak", dalam Jurnal Hukum, Edisi Khusus Vol. 18 Oktober 2011, hlm. 37. Lihat juga Syamsul Anwar, Hukum Perjanjian Syariah: Studi tentang Teori Akad Dalam Fikih Muamalat, (Jakarta: Raja Grafindo Persada,2007), hlm. 8487. Herlien Budiono, Asas Keseimbangan Bagi Hukum Perjanjian Indonesia, (Bandung: Citra Aditya Bakti, 2006), hlm. 95. 
Pokok dari asas konsensualisme menyatakan bahwa pada dasar terjadinya hubungan hukum berupa perjanjian adalah kehendak atau kata sepakat para pihak tanpa perlu dipenuhinya persyaratan formal tertentu. Para pihak bebas berkehendak untuk membuat kontrak dengan siapapun, menentukan isi dan bentuk kontrak. Mereka bebas menyusun klausula-klausula dari kontrak tersebut tanpa campur tangan pihak lain. Pembatasannya adalah selama hal itu tidak melanggar larangan sebagaimana yang diatur dalam al-Qur'an dan as-Sunnah. Campur tangan lain bisa lahir apabila berasal dari negara melalui peraturan perundang-undangan yang menetapkan ketentuan-ketentuan yang diperkenankan atau yang dilarang. Dapat pula berasal dari Pengadilan berupa putusan Pengadilan yang membatalkan klausul perjanjian atau seluruh perjanjian tersebut, atau berupa putusan yang berisi bahwa suatu perjanjian batal demi hukum. ${ }^{6}$

Selanjutnya kesepakatan tersebut menimbulkan kekuatan mengikat bagi para pihak untuk melaksanakan sebagaimana layaknya undang-undang (pacta sun servanda), yang oleh karenanya harus dipatuhi dan dihormati oleh para pembuatnya, karena kontrak tersebut merupakan undang-undang bagi mereka yang membuatnya. Asas kekuatan mengikatnya kontrak, merupakan landasan penting di dalam hukum kontrak bahwa orang harus mematuhi janji. Aspek inilah yang menjadi dasar bagi para pihak di dalam kontrak terikat atau wajib melaksanakan perjanjian. $^{7}$ Di dalam Al-

${ }^{6}$ P. Lindawaty S.Sewu, Aspek Hukum Perjanjian Baku dan Posisi Berimbang Para Pihak Dalam Perjanjian Waralaba, (Bandung: Disertasi (S3) Program Doktor Ilmu Hukum Program Pascasarjana Universitas Katolik Parahyangan, 2007), hlm. 17-18.

Ridwan Khairandy, Landasan Filosofis Kekuatan Mengikatnya Kontrak, dalam Jurnal Hukum, Edisi Khusus Vol. 18 Oktober 2011, hlm.38.
Qur'an dan Hadist terdapat banyak perintah agar para pihak memenuhi janji. Dalam kaidah usul fikih, 'perintah itu pada asasnya menunjukkan wajib'. Oleh karenanya, janji itu bersifat mengikat dan wajib dipenuhi. ${ }^{8}$

Berangkat dari asas-asas di atas meskipun para pihak mempunyai kebebasan untuk menentukan isi maupun bentuk kontrak, bebas menyusun klausulaklausula untuk kepentingan mereka, namun kebebasan tersebut haruslah sesuai dan/atau tidak bertentangan dengan ketentuan/norma agama maupun undangundang yang berlaku, misalnya dalam AlQur'an ada ketentuan bahwa para pihak dilarang melakukan transaksi yang mengandung unsur riba, begitupun di dalam BW maupun KUHP juga terdapat larangan perjudian.

Sebagaimana kita ketahui dunia bisnis sangat erat hubungannya dengan kontrak (akad) begitu juga dalam dunia bisnis islam sehingga dibutuhkan sebuah kontrak yang tidak bertentangan dengan hukum kontrak syari'ah yang melarang riba dan bunga. Istilah riba dalam praktik bisnis, hampir tidak pernah ditemukan. Namun, istilah yang muncul secara eksplisit adalah bunga. Perdebatan pemikiran mengenai riba dan bunga menunjukkan kesamaan di antara keduanya. Riba dalam konsepsi sekarang ini telah berubah dan berevolusi berbentuk bunga.'

\section{Pembahasan}

A. Defenisi Riba

Riba merupakan salah satu jenis transaksi ekonomi yang secara riil dijalankan dan berkembang dalam masyarakat Arab. Transaksi jenis ini

8 Syamsul Anwar, Hukum Perjanjian Syariah: Studi Tentang Teori Akad dalam Fikih Muamalat, (Jakarta: Raja Grafindo Persada, 2007), hlm.89.

9 Nurjihad, Jurnal Hukum IUS QUIA IUSTUM NO. 3 VOL. 20 JULI 2013, hlm. 442. 
sudah ada sejak sebelum Islam datang, sebuah masa yang dalam perspektif historis Islam disebut sebagai "masa Jahiliyyah". Praktik riba merupakan fenomena sosial-ekonomi yang mewarnai aktivitas ekonomi masyarakat dan tergolong cukup populer bagi masyarakat Arab masa Jahiliyyah.

Kata riba berasal dari bahasa Arab raba>-yarbu> yang berarti bertambah. ${ }^{10}$ Secara linguistik riba juga berarti tumbuh dan membesar. ${ }^{11}$ Secara leksikal inti dari kata riba adalah bertambah, membesar, menjadi lebih banyak, tumbuh, berkembang atau naik. ${ }^{12}$ Sedangkan menurut istilah teknis, riba berarti pengambilan tambahan dari harta pokok atau modal secara bathil. ${ }^{13}$ Meskipun berbeda-beda, namun secara umum riba berarti bertambah, baik secara kualitatif maupun kuantitatif, ${ }^{14}$ baik dalam transaksi jualbeli maupun pinjam-meminjam secara bathil atau bertentangan dengan prinsip muamalat dalam Islam. ${ }^{15}$

Jumhur ulama sepanjang sejarah Islam dari berbagai mazhahib

${ }^{10}$ Prof. Drs. H. Akh. Minhaji, M.A., Ph. D.,dkk, Antologi Hukum Islam: Pps prodi HI Pasca, (Yogyakarta: Sukses Offset, 2010), hlm. 115.

11 Atabik Ali dan Zuhdi Mukhdlor (Penyusun), Kamus Krapyak Al-'Asri: ArabIndonesia, (Yogyakarta: Yayasan Ali Maksum Pondok Pesantren Krapyak, 1996), hlm. 952.

12 Prof. Dr. H. Syamsul Anwar, Studi Hukum Islam Kontemporer, (Jakarta: RM Books), hlm. 100.

${ }^{13}$ Sayyid Sabiq, Fikih Sunnah 12, cet.I, (Bandung: PT. Al-Ma'rif, 1987), hlm. 125.

${ }_{14}$ Abdullah Saeed, Islamic Banking and Interest, A Study of Prohibition of Riba and its Contemporary Interpretation, (Leiden: E.J. Brill, 1996), hlm. 20.

15 Ahmad Azhar Basyir, Hukum Islam tentang Riba, Utang-Piutang, Gadai, (Bandung: PT Ma'rif, 1983), hlm. 27. fiqhiyyah memberikan definisi riba. Di antaranya: ${ }^{16}$

1. Badr Ad Din Al Ayni pengarang Umdatul Qari Syarah Shahih Al Bukhari: "Prinsip utama dalam riba adalah penambahan. Menurut syariah riba berarti penambahan atas harta pokok tanpa adanya transaksi bisnis riel."

2. Imam Sarakhsi dari mazhab Hanafi: "Riba adalah tambahan yang disyaratkan dalam transaksi bisnis tanpa adanya iwadh (atau padanan yang dibenarkan syariah atas penambahan tersebut."

3. Raghib Al Asfahani : "Riba adalah penambahan atas harta pokok"

4. Imam An Nawawi dari mazhab Syafi'i: "Riba adalah penambahan atas pinjaman seiring bertambahnya waktu". Dari penjelasan Imam Nawawi di atas sangat jelas bahwa salah satu bentuk riba yang dilarang $\mathrm{Al}$ Qur'an dan As Sunnah adalah penambahan atas harta pokok karena unsur waktu. Dalam dunia perbankan hal tersebut dikenal dengan bunga kredit sesuai lama waktu pinjaman.

5. Qatadah: "Riba jahiliyah adalah seseorang yang menjual barangnya secara tempo hingga waktu tertentu. Apabila telah datang saat pembayaran dan si pembeli tidak mampu membayar, maka ia memberikan bayaran tambahan atas penangguhan."

6. Zaid bin Aslam: "Yang dimaksud dengan riba jahiliyyah yang berimplikasi pelipat-gandaan sejalan dengan waktu adalah seseorang yang memiliki piutang atas mitranya. Pada saat jatuh

16 Muhammad Syafi'i Antonio, Bank Syari'ah: Dari Teori ke Praktik, (Jakarta: Gema Insani Press,2001), hlm. 38-41. 
tempo ia berkata: 'bayar sekarang atau tambah."”

7. Mujahid: "Mereka menjual dagangannya dengan tempo. Apabila telah jatuh tempo dan (tidak mampu bayar) si pembeli memberikan 'tambahan' atas tambahan waktu."

8. Ja'far Ash Shadiq dari kalangan Syiah: "Ja'far Ash Shadiq berkata ketika ditanya mengapa Allah mengharamkan riba - "Supaya orang tidak berhenti berbuat kebajikan. Karena ketika diperkenankan untuk mengambil bunga atas pinjaman, maka seseorang tidak berbuat ma'ruf lagi atas transaksi pinjam-meminjam dan sejenisnya. Padahal qard bertujuan untuk menjalin hubungan yang erat dan kebajikan antarmanusia."

9. Imam Ahmad bin Hanbal, pendiri madzhab Hanbali "Imam Ahmad bin Hanbal ketika ditanya tentang riba beliau menjawab: Sesungguhnya riba itu adalah seseorang memiliki hutang maka dikatakan kepadanya apakah akan melunasi atau membayar lebih. Jikalau tidak mampu melunasi, ia harus menambah dana (dalam bentuk bunga pinjam) atas penambahan waktu yang diberikan."

\section{B. Pelarangan Riba Sebelum Islam}

Konsep riba sebenarnya telah lama dikenal dan mengalami perkembangan pemaknaan. Sebelum masuk peradaban Islam, kajian riba telah dibahas oleh kalangan agama Hindu, Budha, Yahudi, Yunani, Romawi dan Kristen. ${ }^{17}$

17 Veithzal Rivai, et.al, Bank and
Financial $\quad$ Institution
Conventionaland Sharia System, (Jakarta:
RajaGrafindo Persada, 2007), hlm. 761. Lihat

Konsep riba di kalangan Yahudi, yang dikenal dengan istilah "neshekh" dinyatakan sebagai hal yang dilarang dan hina. Pelarangan ini banyak terdapat dalam kitab suci mereka, baik dalam Old Testament (Perjanjian lama) maupun dalam undang-undang Talmud. Banyak ayat dalam Old Testament yang melarang pengenaan bunga pada pinjaman kepada orang miskin dan mengutuk usaha mencari harta dengan membebani orang miskin dengan riba. $^{18}$

Pada masa Yunani dan Romawi Kuno, praktek riba merupakan tradisi yang lazim berlaku. Pada masa Yunani sekitar abad VI SM hingga 1 $\mathrm{M}$, terdapat beberapa jenis bunga yang bervariasi besarnya. Sementara itu, pada masa Romawi, sekitar abad V SM hingga IV M, terdapat undangundang yang membolehkan penduduknya mengambil bunga selama tingkat bunga tersebut sesuai dengan tingkat maksimal yang dibenarkan hukum (maximum legal rate). ${ }^{19}$ Meskipun demikian, praktik pengambilan bunga tersebut dicela oleh para ahli filsafat Yunani, diantaranya Plato (427-347 SM) dan Aristoteles (384-322 SM), begitu pula para ahli filsafat Romawi, seperti Cato (234-149 SM), Cicero (106-43 SM) dan Seneca (4 SM-65 M) mengutuk praktik bunga, yang digambarkannya sebagai tindakan tidak manusiawi. ${ }^{20}$

Konsep riba di kalangan
Kristen mengalami perbedaan

juga Muhammad Syafi'i Antonio, Bank Syari'ah: Dari Teori ke Praktik, ( Jakarta: Gema Insani Press, 2001), hlm. 42.

${ }_{18}$ Muhammad Syafi'i Antonio, Bank Syari'ah: Dari Teori ke Praktik, ( Jakarta: Gema Insani Press, 2001), hlm. 43.

$$
{ }^{19} \text { Ibid., }
$$

20 Abdul Azim Islahi, Economic Concepts of Ibn Taimiyah, (London: The Islamic Foundation, 1988), hlm. 124. 
pandangan, yang secara umum dapat dikelompokkan menjadi tiga periode sebagai berikut: ${ }^{21}$

Pertama, pandangan para pendeta awal Kristen (abad I-XII) yang mengharamkan riba dengan merujuk pada Kitab Perjanjian Lama dan undang-undang dari gereja. Pada abad IV M, gereja Katolik Roma melarang praktik riba bagi para pendeta, yang kemudian diperluas bagi kalangan awam pada abad V M. Pada abad VIII M, di bawah kekuasaan Charlemagne, gereja Katolik Roma mendeklarasikan praktik riba sebagai tindakan kriminal.

Kedua, pandangan para sarjana Kristen (abad XII-XVI) yang cenderung membolehkan bunga, dengan melakukan terobosan baru melalui upaya melegitimasi hukum, bunga dibedakan menjadi interest dan usury. Menurut mereka, interest adalah bunga yang diperbolehkan, sedangkan usury adalah bunga yang berlebihan. Para sarjana Kristen yang memberikan kontribusi pemikiran bunga ini adalah Robert of Courcon (1152-1218), William of Auxxerre (1160-1220), St. Raymond of Pennaforte (1180-1278), St. Bonaventure (1221-1274) dan St. Thomas Aquinas (1225-1274).

Ketiga, pandangan para reformis Kristen (abad XVI-1836) seperti Martin Luther (1483-1536), Zwingli (1454-1531), Bucer (1491-1551) dan John Calvin (1509-1564) yang menyebabkan agama Kristen menghalalkan bunga (interest). Pada periode ini, Raja Henry VIII memutuskan berpisah dengan Gereja Katolik Roma, dan pada tahun 1545 bunga (interest) resmi dibolehkan di

21 Anita Rahmawati, Riba Dalam Perspektif Keuangan Islam, hlm. 5-6, dalam http://p3m.stainkudus.ac.id/files/ Anita.pdf di akses tanggal 15 Oktober 2018 jam 14.00 WIB.
Inggris asalkan tidak lebih dari 10\%. Kebijakan ini kembali diperkuat oleh Ratu Elizabeth I pada tahun 1571.

Perkembangan selanjutnya setelah itu, maka seluruh praktik operasionalisasi perbankan modern yang mulai tumbuh dan berkembang sejak abad XVI M menggunakan sistem bunga. Sistem bunga ini mulai tumbuh, mengakar, dan mendarahdaging dalam industri perbankan modern sehingga sulit untuk dipisahkan. Bahkan mereka beranggapan bahwa bunga adalah pusat berputarnya sistem perbankan. Jika tanpa bunga, maka sistem perbankan menjadi tak bernyawa dan akhirnya perekonomian akan lumpuh. ${ }^{22}$

C. Pelarangan Riba dalam Islam

Sebagaimana kita ketahui bahwa praktik riba sudah berlangsung jauh sebelum Islam lahir. Aktivitas ini sudah merupakan bagian dari masyarakat dari masa ke masa. Unsur ketidakadilan yang terkandung dalam sistem ini telah membawa kerusakan dan kehancuran yang sangat serius. Sejarah mencatat bahwa Plato, Aristoteles dari Yunani serta Cicero dan Cato dari Romawi begitu mengecam aktivitas riba.

Dalam Alquran, pelarangan riba diturunkan tidak sekaligus melainkan diturunkan dalam empat bertahap. Tahap-tahap pelarangan riba dalam Al-Quran dapat dijelaskan sebagai berikut: ${ }^{23}$

Tahap pertama, menolak anggapan bahwa pinjaman riba yang

${ }^{22}$ Muhammad Abdul Mannan, Islamic Economic, Theory and Practice, terj. Nastangin, (Yogyakarta : Dana Bhakti Wakaf, 1997), hlm. 165.

23 Muhammad Syafi'i Antonio, Bank Syari'ah: Dari Teori ke Praktik, ( Jakarta: Gema Insani Press, 2001), hlm. 48-51. 
pada zabirnya seolah-olah menolong mereka yang memerlukan sebagai perbuatan taqarrub (mendekatkan diri) kepada Allah (QS. Ar-Rum: 39).

Tabap kedua, riba digambarkan sebagai sesuatu yang buruk. Allah SWT mengancam akan memberi balasan yang keras kepada orang Yahudi yang memakan riba (QS. AnNisa': 160-161).

Tabap ketiga, pelarangan riba dengan dikaitkan pada suatu tambahan yang berlipat ganda (QS. Al Imran: 130). Ayat ini turun setelah perang Uhud, yaitu tahun ke-3 Hijriyah. Secara umum istilah berlipat ganda harus dipahami sebagai sifat bukan syarat sehingga pengertiannya adalah yang diharamkan bukan hanya yang berlipat ganda saja sementara yang sedikit, maka tidak haram, melainkan sifat riba yang berlaku umum pada waktu itu adalah berlipat ganda.

Tahap keempat, merupakan tahap terakhir di mana Allah dengan tegas dan jelas mengharamkan apapun jenis tambahan yang diambil dari pinjaman (QS. Al-Baqarah: 278279).

Pelarangan riba dalam Islam tidak hanya merujuk pada AlQuran, melainkan juga Hadist. Hal ini sebagaimana posisi umum hadits yang berfungsi untuk menjelaskan lebih lanjut aturan-aturan yang telah digariskan melalui Al-Quran.

D. Macam-Macam Riba

Pada dasarnya riba terbagi menjadi dua macam yaitu riba akibat hutang piutang yang telah dijelaskan tentang keharamannya dalam alQur'an, dan riba jual beli yang juga telah dijelaskan boleh dan tidaknya dalam bertransaksi dalam as-Sunnah.

1. Riba akibat hutang-piutang disebut Riba Qard (ربا القرض), yaitu suatu manfaat atau tingkat kelebihan tertentu yang disyaratkan terhadap yang berhutang (muqtarid), dan Riba Jabiliyah (ربـا الجاهليـ), yaitu hutang yang dibayar dari pokoknya, karena si peminjam tidak mampu membayar hutangnya pada waktu yang ditetapkan. ${ }^{24}$

2. Riba akibat jual-beli disebut Riba Fadl (ربـا الفضل), yaitu pertukaran antar barang sejenis dengan kadar atau takaran yang berbeda dan barang yang dipertukarkan termasuk dalam jenis barang ribawi, dalam hadits Ubadah bin Shamit ${ }^{25}$ disebutkan bahwa seseorang menukar barang berupa emas harus dengan emas pula yang sepadan dan beratnya juga harus sama, perak dengan perak dan harus diserahterimakan secara langsung, Riba Nasi'ah (ربـا النسئه), yaitu penangguhan atas penyerahan atau penerimaan jenis barang ribawi yang diperlukan dengan jenis barang ribawi lainnya. Riba nasi'ah muncul dan terjadi karena adanya perbedaan, perubahan, atau tambahan antara yang diserahkan saat ini dan yang diserahkan kemudian. ${ }^{26}$

24 Muhammad Syafi'i Antonio, Bank Syari'ah bagi Bankir dan Praktisi Keuangan, cet. I, (Jakarta: Tazkia Institute, 1999), hlm. 77-78.

${ }^{25}$ Diriwayatkan oleh Muslim dalam Shahihnya dalam kitab al-Musaqat, bab: Menjual emas dengan perak secara kontan, nomor 1587 , lihat juga Abu Daud dalam Sunannya nomor 3348, diriwayatkan juga olwh an-Nasa'i nomor 4562, diriwayatkan juga oleh Ibnu Majah nomor, 2253-2254.

${ }^{26}$ Tim Pengembangan Syari'ah Institut

Bankir Indonesia, Konsep, Produk dan Implementasi Operasional Bank Syari'ah, (Jakarta: Djambatan, 2002), hlm. 39-40. 
E. Pandangan Kaum Modren tentang Riba

Kaum modernis memandang riba lebih menekankan pada aspek moralitas atas pelarangannya, dan menomor-duakan "legal-form" riba, seperti yang ditafsirkan dalam fiqh. Mereka (kaum modernis) adalah Fazlur Rahman (1964), Muhammad Asad (1984), Sa'id al-Najjar (1989), dan Abd al-Mun'im al-Namir (1989).

Menurut Muhammad Asad:

"Garis besarnya, kekejian riba (dalam arti di mana istilah digunakan dalam al-Qur'an dan dalam banyak ucapan Nabi SAW) terkait dengan keuntungan-keuntungan yang diperoleh melalui pinjamanpinjaman berbunga yang mengandung eksploitasi atas orangorang yang berekonomi lemah orang-orang kuat dan kaya...dengan menyimpan definisi ini di dalam benak kita menyadari bahwa persolan mengenai jenis transaksi keuangan mana yang jatuh ke dalam kategori riba, pada akhirnya, adalah persoalan moralitas yang sangat terkai dengan motivasi sosio-ekonomi yang mendasari hubungan timbal-balik antara si peminjam dan pemberi pinjaman.",27

Menurut pemikir modern yang lain adalah Abdullah Yusuf Ali, beliau mendefiniskan riba adalah:

"Tidak dapat disangsikan lagi tentang pelarangan riba. Pandangan yang biasa saya terima seakan-akan menjelaskan, bahwa tidak sepantasnya memperoleh keuntungan dengan menempuh jalan perdagangan yang terlarang, di antaranya dengan pinjam meminjam terhadap emas dan

${ }^{27}$ Abdullah Saeed, Islamic Banking and Interest: a Study of the Prohibition of Riba and its Contemporary Interpretation, (Leiden; New york; Koln; Brill, 1996), hlm. 42. perak serta kebutuhan bahan makanan meliputi gandum, gerst (seperti gandum yang dipakai dalam pembuatan bir), kurma, dan garam. Menurut pandangan saya seharusnya larangan ini mencakup segala macam bentuk pengambilan keuntungan yang dilakukan secara berlebih-lebihan dari seluruh jenis komoditi, kecuali melarang pinjaman kredit ekonomi yang merupakan produk perbankan modern.",28

Sedangkan Fazlur Rahman berpendapat bahwa riba:

"Mayoritas kaum muslim yang bermaksud baik dengan bijaksana tetap berpegang teguh pada keimanannya, menytakan bahwa al-Qur'an melarang seluruh bunga bank. (menanggapi penjelasan tersebut) sedih rasanya pemahaman yang mereka dapatkan dengan cara mengabaikan bentuk riba yang bagaimanakah yang menurut sejarah dilarang, mengapa al-Qur'an mencelanya sebagai perbuatan keji dan kejam mengapa menganggapnya sebagai tindakan eksploitatif serta melarangnya, dan apa sebenarnya fungsi bunga bank pada saat ini.", ${ }^{29}$

Bagi kaum modernis tampak dengan jelas bahwa apa yang diharamkan adalah adanya eksploitasi atas orang-orang miskin, bukan pada konsep bunga itu sendiri (legal-form) menurut hukum Islam, apa yang diharamkan adalah tipe peminjaman yang berusaha mengambil untung dari penderitaan orang lain.

F. Teori Bunga

Secara etimologis, bunga dalam The American Heritage Dictionary of the English Language didefinisikan sebagai interest is a charge for a financial loan,
${ }^{28} \mathrm{Ibid}$.
${ }^{29}$ Ibid., 
usually a percentage of the amount loaned. ${ }^{30}$ Kata "interest" berasal dari bahasa Latin "intere" yang berarti untuk kehilangan "to be lost". Sebagian lain mengatakan bahwa interest berasal dari bahasa Latin "interesee" yang berarti datang di tengah (to come in between) yaitu kompensasi kerugian yang muncul di tengah transaksi jika peminjam tidak mengembalikan sesuai waktu (compensation or penalty for delayed repayment of a loan). Pada perkembangan selanjutnya, "interest" bukan saja diartikan sebagai ganti rugi akibat keterlambatan pembayaran hutang, tetapi diartikan juga sebagai ganti rugi atas kesempatan yang hilang (opportunity loss). ${ }^{31}$

$$
\text { Berbagai 'pembenaran' }
$$
pemikiran teori mengenai bunga sebagai instrumen perekonomian yang penting banyak ditemukan. Di antaranya pemikiran teori bunga moneter yang terakhir dilakukan oleh Keynes. Ia memandang bahwa bunga bukan sebagai harga atau balas jasa atas tabungan, tetapi bersifat pembayaran untuk pinjaman uang. Secara umum teori bunga moneter memandang bahwa pembayaran bunga sebagai tindakan opportunitas untuk memperoleh keuntungan dan tindakan meminjamkan uang. Oleh karena itu, Keynes menyebutnya sebagai motif spekulasi. Motif ini didefinisikan sebagai usaha untuk menjamin keuntungan di masa yang akan datang. Dalam teori ini, aktivitas spekulasi yang dilakukan pelaku

30 Wirdyaningsih, et.al, Bank dan Asuransi Islam di Indonesia, ( Jakarta: Kencana, 2005), hlm. 21.

31 Veithzal Rivai, et.al, Bank and Financial Institution Manajement Conventionaland Sharia System, (Jakarta: RajaGrafindo Persada, 2007), hlm. 762 Lihat juga Adiwarman Karim, Bank Islam: Analisis Fiqh dan Keuangan, (Jakarta: RajaGrafindo Persada, 2007), hlm. 42. ekonomi akan mempengaruhi suku bunga dan silih berganti, dan akhirnya akan mempengaruhi investasi, tingkat produksi dan kesempatan kerja. ${ }^{32}$ Sementara itu, jelas dalam Islam melarang segala bentuk spekulasi karena aktivitas dapat dikategorikan sebagai maysir (gambling).

Pada kenyataannya berbagai teori bunga yang muncul sejumlah kelemahan yaitu tidak mampu menjelaskan secara pasti apakah bunga diperlukan dalam suatu perekonomian atau apakah bunga berperan mendorong investasi nyata dan bukan mendorong untuk berspekulasi. Oleh karena itu, gugatan kemudian mulai muncul berkenaan dengan teori bunga tersebut sampai akhirnya muncullah tawaran solusi alternatif dengan munculnya teori bagi hasil di perbankan syari'ah. ${ }^{33}$

G. Riba dan Bunga dalam Sistem Hukum Kontrak Syari'ah

Berbicara tentang riba dan bunga dalam kontrak syari'ah memiliki hubungan yang erat dengan asas-asas kontrak syari'ah selain landasan normatif berupa ketentuan yang menjadi dasar dalam perjanjian, bahkan aturan/ketentuan yang dimaksud disusun dengan berakar dan bertumpu pada suatu asas hukum, yaitu nilai-nilai yang diyakini benar dan adil sehingga tidak menimbulkan riba dan bunga.

Berkaitan dengan hukum perjanjian/kontrak syariah dikenal beberapa asas hukum yang melandasinya. Fathurrahman Jamil

${ }^{32}$ Muhamad, Teknik Perhitungan Bagi Hasil dan Profit Margin pada bank Syari'ah, (Yogyakarta: UII Press, 2001), hlm. 14-15.

33 Anita Rahmawati, Riba Dalam Perspektif Keuangan Islam, hlm.15, dalam http://p3m.stainkudus.ac.id/files/ Anita.pdf di akses tanggal 15 Oktober 2018 jam 14.00 WIB. 
mengemukakan adanya 6 (enam) asas, yaitu: asas kebebasan, asas persamaan atau kesetaraan, asas keadilan, asas kerelaan, asas kejujuran dan kebenaran, dan asas tertulis. ${ }^{34}$ Adapun Syamsul Anwar menyebutkan ada 8 (delapan) asas, yaitu: asas ibahah, asas kebebasan ber-akad, asas konsensualisme, asas janji itu mengikat, asas keseimbangan, asas kemaslahatan, asas amanah dan asas keadilan. ${ }^{35}$

Pada umumnya para ahli hukum menyebutkan ada 3 (tiga) asas pokok/fundamental yang melingkupi hukum kontrak, dimana satu dengan lainnya saling berkaitan yaitu: asas konsensualisme, asas kebebasan berkontrak dan asas kekuatan mengikatnya kontrak. Konsensualitas menyangkut terjadinya persetujuan, prinsip kekuatan mengikat menyangkut akibat persetujuan, sedangkan prinsip kebebasan berkontrak terutama berurusan dengan isi persetujuan.

Pandangan bahwa perjanjian sudah dilahirkan pada saat atau detik tercapainya konsensus atau kesepakatan, atau dengan perkataan lain perjanjian itu sah apabila hal-hal pokok sudah disepakati dan tidak perlu formalitas, ${ }^{36}$ merupakan perkembangan hukum dari tatanan hukum Romawi yang dimana persetujuan baru terjadi pada saat benda atau barang diserahkan. Pada awalnya hukum Romawi berpegang teguh pada persyaratan yang ketat

34 Fathurrahman Jamil et.al., Hukum Perjanjian Syariah dalam Kompilasi Hukum Perikatan, (Bandung: Citra Adutya Bakti), hlm. 249.

35 Syamsul Anwar, Hukum Perjanjian Syariah: Studi tentang Teori Akad Dalam Fikih Muamalat, (Jakarta: Raja Grafindo Persada, 2007), hlm. 83-92.

${ }^{36}$ Subekti, Hukum Perjanjian, (Jakarta: Intermasa, 1984), hlm. 15. bahwa persetujuan-persetujuan, dengan beberapa kekeualian, harus memenuhi persyaratan-persyaratan tertentu untuk dapat dipandang sebagai persetujuan yang telah diadakan. ${ }^{37}$

Adapun asas kebebasan berkontrak di dalam sistem civil law dan common law lahir dan berkembang seiring dengan pertumbuhan aliran filsafat yang menekankan individualisme dan pasar bebas. Pada abad sembilan belas, kebebasan berkontrak sangat diagungkan baik oleh para filosuf, ekonom, sarjana hukum, maupun pengadilan. Pada saat itu, kebebasan berkontrak memiliki kecenderungan ke arah kebebasan tanpa batas (unrestricted freedom of contract). ${ }^{38}$ Dalam konteks sistem hukum Islam, pada mulanya kebebasan berkontrak tidak menjadi wacana sarjana hukum muslim. Kondisi demikian dipengaruhi kecenderungan tradisional mereka yang mengkategorisasikan transaksi yang diperbolehkan dan legal (halal), dan yang dilarang dan illegal (haram). Pada periode permulaan ada kerisauan terhadap semua kontrak yang bebas akan kekhawatiran riba dan uncertainty (gharar), dapat dikategorikan sebagai transaksi yang harus dibatalkan. ${ }^{39}$

\begin{tabular}{lr}
\multicolumn{1}{c}{ Dalam } & perkembangan \\
berikutnya, asas & kebebasan \\
berkontrak ini & mendapatkan \\
pembatasan dalam pemberlakuannya.
\end{tabular}

${ }^{37}$ P. Lindawaty S.Sewu, Aspek Hukum Perjanjian Baku dan Posisi Berimbang Para Pihak Dalam Perjanjian Waralaba, (Bandung: Disertasi (S3) Program Doktor Ilmu Hukum Program Pascasarjana Universitas Katolik Parahyangan, 2007), hlm. 71-72.

Ridwan Khairandy, Landasan Filosofis Kekuatan Mengikatnya Kontrak, dalam Jurnal Hukum, Edisi Khusus Vol. 18 Oktober 2011, hlm.39-40.

${ }^{39}$ Ibid., hlm. 47. 
Terdapat beberapa alasan yang menyebabkan perjanjian tidak lagi mengikat pihak-pihak yang membuatnya dalam hal terjadi kekhilafan (dwaling), paksaan (dwang), dan penipuan (bedrog), persetujuan tanpa sebab, atau dibuat karena sesuatu sebab yang palsu atau terlarang (Pasal 1321 jo.1334 BW). Dengan demikian pandangan/pemikiran kalangan sarjana hukum muslim yang memberikan pembatasan terhadap asas kebebasan berkontrak merupakan pandangan lama yang sesuai dan bertahan hingga kini.

Dalam perspektif hukum Islam, kontrak dilaksanakan pertama kali mengacu kepada asas ibahah yang merupakan asas umum hukum Islam dalam bidang muamalat. Asas ini mengajarkan bahwa segala sesuatu (perjanjian) itu diperbolehkan, kecuali ada dalil yang melarangnya. Dengan perkataan lain selama tidak ada dalil yang melarangnya, maka hukumnya boleh dilaksanakan. Beberapa dalil/ketentuan yang secara eksplisit diatur adalah pelarangan riba, perjudian (maisir), ketidakjelasan (gharar), haram dan zalim. Selama tidak melanggar ketentuan di atas, maka kegiatan tersebut dapat dikatakan sesuai dengan prinsip syariah.

Dalam hukum kontrak syariah, larangan terhadap transaksi riba ini mencerminkan asas keseimbangan dalam memikul risiko yang dalam konsep riba hanya debitur yang memikul segala risiko atas kerugian usaha, sementara kreditor bebas sama sekali dan harus mendapat persentase tertentu sekalipun pada saat dananya mengalami kembalian negatif. ${ }^{40}$

${ }^{40}$ Syamsul Anwar, Hukum Perjanjian Syariah: Studi tentang Teori Akad Dalam Fikih
Demikianlah, hukum perjanjian Islam tetap menekankan perlunya keseimbangan, baik keseimbangan antara apa yang diberikan dan apa yang diterima maupun keseimbangan dalam memikul risiko.

Islam sangat melarang praktik riba/bunga, sehingga di sisi lain Islam mendorong umatnya untuk melakukan investasi. Dalam hal ini, terdapat perbedaan mendasar antara antara investasi dan membungakan uang. Perbedaan tersebut dapat ditelaah dari definisi hingga maknanya masing-masing. Investasi adalah kegiatan usaha yang mengandung resiko karena berhadapan dengan unsur ketidakpastian. Dengan demikian, perolehan return-nya tidak pasti dan tidak tetap. Sedangkan membungakan uang adalah kegiatan usaha yang kurang mengandung resiko karena perolehan return-nya berupa bunga yang relatif pasti dan tetap. ${ }^{41}$

Dengan demikian jelas bahwa praktik riba/bunga sangatlah merugikan salah satu pihak dalam kontrak, dikarenakan terjadinya eksploitasi pelaku ekonomi atas pelaku yang lain dan eksploitasi sistem atas pelaku ekonomi. Pelarangan praktik ini bertujuan agar terwujud aktifitas ekonomi yang adil dan maslahat antara pemilik harta (modal) dengan usaha, serta pemikulan resiko dan akibatnya secara

Muamalat, (Jakarta: Raja Grafindo Persada), , 2007, hlm. 90.

${ }^{41}$ Muhammad Syafi'i Antonio, Bank Syari'ah: Dari Teori ke Praktik ,( Jakarta: Gema Insani Press, 2001), hlm. 59. Lihat Juga M. Taufiq, dan Muklisin Purnomo, "Model Pemberdayaan Aset Wakaf Masjid Secara Produktif di Masjid Jogokariyan Yogyakarta", Perada: Jurnal Studi Islam Kawasan Kemelayuan, Vol.1, No.2, 2018. 
berani dan penuh rasa tanggung jawab.

Asas-asas lainnya merupakan asas pendukung yang sifatnya melengkapi serta merupakan elaborasi dan pengembangan dari asas ibahah. Asas konsensualisme, kebebasan berkontrak dan kekuatan mengikatnya kontrak, sebagaimana dikemukakan ahli hukum pada umumnya, memang merupakan asas yang pokok dan penting, khususnya dalam hukum kontrak non syariah. Namun dalam kontrak syariah, penting tidaknya asas yang melandasi sangat berkaitan juga dengan tujuan dari diadakannya akad/perjanjian itu sendiri.

Menurut hukum Islam, sesungguhnya tujuan akad/perjanjian adalah mewujudkan akibat hukum yang pokok dari akad Namun demikian tujuan akad berbeda dengan akibat hukum pokok akad. Perbedaannya terletak pada sudut mana melihatnya. Tujuan akad adalah maksud pokok yang hendak diwujudkan oleh para pihak, seperti memindahkan pemilikan atas suatu benda dengan imbalan dalam akad jual beli. Apabila maksud tersebut dapat direalisasikan sehingga terjadi perpindahan milik, maka perpindahan milik tersebut adalah akibat hukum pokok. Dengan perkataan lain, tujuan akad adalah maksud para pihak ketika membuat akad, sedangkan akibat hukum pokok adalah hasil yang dicapai ketika akad direalisasikan. ${ }^{42}$

Terealisasikannya akibat hukum pokok dari akad, pada intinya merupakan manifestasi dari kehendak sesungguhnya para pihak. Terpenuhinya kehendak tersebut maka didalamnya selain mengandung

42 Syamsul Anwar, Hukum Perjanjian Syariah: Studi tentang Teori Akad Dalam Fikih Muamalat, (Jakarta: Raja Grafindo Persada), , 2007, hlm. 219. unsur kemaslahatan sekaligus keadilan yang diharapkan bagi para pihak. Dalam perspektif filsafat hukum Islam, keadilan dan kemaslahatan adalah merupakan tujuan yang dikehendaki. Salah satu konsep penting dan fundamental adalah konsep maqasid at-tasyri' atau maqasid al-syariah yang menegaskan disyariatkannya hukum Islam adalah untuk mewujudkan dan memelihara maslahat umat manusia.

Berbagai asas atau prinsip yang berkembang dalam hukum kontrak merupakan sumber yang melatarbelakangi ketentuan hukum sekaligus menghidupi penerapan kontrak/perjanjian dalam sistem hukum yang berlaku, yang di dalamnya terkandung nilai-nilai kemaslahatan dan keadilan. Nilai-nilai kemaslahatan dan keadilan ini haruslah merupakan ruh dalam setiap kontrak yang dilakukan oleh para pihak. Dengan demikian asas kemaslahatan dan keadilan mempunyai kedudukan utama dalam kontrak syari'ah.

H. Diskursus Bunga Bank di Indonesia Wacana bunga bank di Indonesia terbagi dalam dua kelompok, yaitu mazhab tekstual dan kontekstual. Mazhab tekstual cenderung mengharamkan bunga bank, kelompok ini sangat gencar menganjurkan dan mendorong pengembangan bank syariah. Di antara tokohnya adalah M. Syafi'i Antonio, Adiwarman Karim, M. Zuhri, dan lain-lain. ${ }^{43}$

Dalam membicarakan tentang riba, Antonio mengemukakan keempat periodisasi ayat pelarangan riba. Ketika sampai pada ayat ketiga

43 Muslihun Muslim, Fiqh Ekonomi, (Mataram: LKIM, 2005), hlm. 149. 
QS. Ali Imran (3): 130 beliau berpendapat sebagai berikut:

"Secara umum ayat ini harus dipahami bahwa kriteria berlipat ganda bukanlah merupakan syarat dari terjadinya riba (jika bunga berlipat ganda disebut riba, tetapi jika kecil bukan termasuk riba), tetapi ini merupakan sifat umum dari praktik pembungaan uang pada saat ini. Demikian juga ayat ini harus dipahami secara komprehensif dengan ayat 278279 dari QS. Al-Baqarah". ${ }^{44}$

Antonio menandaskan pentingnya menghubungkan ayat 130 QS. Ali Imron dengan QS. AlBaqarah ayat 278-279 tanpa menyebutkan kesimpulan akhirnya, bisa dipastikan maksudnya adalah mengharamkan dalam semua jenis. Selanjutnya, Antonio juga menjelaskan bahwa kriteria berlipat ganda sebagai sifat dari riba dan sama sekali bukan merupakan syarat.

Sementara itu, Adiwarman mengidentifikasi bunga bank dengan memasukkan riba pada penyebab terlarangnya transaksi karena haram selain zatnya. Transaksi yang termasuk dalam kategori ini menurutnya adalah tadlis, ihtikar, bai' najasy, taghrir, dan riba. Larangan riba, dalam pandangannya disebabkan karena melanggar prinsip la tadzlimun wa la tudzlamun tanpa membahasnya secara luas kepada persoalan illat hukum dan aspek moral. Karim juga menyebutkan ada tiga jenis riba, yaitu riba fadl, riba nasi'ah, dan riba jahiliyyah. Bunga bank masuk dalam kategori riba nasi'ah, munculnya riba ini disebabkan adanya perbedaan, perubahan atau tambahan antara

44 Muhammad Syafi'i Antonio, Bank Syari'ah: Dari Teori ke Praktik, ( Jakarta: Gema Insani Press, 2001), hlm. 49. barang yang diserahkan hari ini dengan barang yang diserahkan kemudian. Meskipun membahas "kezaliman", Adiwarman tidak menjadikan kezaliman itu sebagai illat hukumnya. ${ }^{45}$

Kelompok kedua adalah kelompok kontekstual yang berpendapat bahwa illat hukum yang dijadikan patokan tentang keharaman "tambahan" yang diterima dari pinjaman adalah dzulm (kezaliman). Di antara tokohnya adalah A. Hassan, M. Quraish Shihab, dan Umar Shihab. ${ }^{46}$

Hasan berpendapat bahwa riba nasi'ah adalah haram sepanjang tambahan atau kelebihan ini bersifat berlipat ganda dan eksploitatif (dzulm). Menurutnya, riba seperti inilah yang sebenarnya diharamkan, yang pada zaman Jahiliyyah banyak dipraktikkan. Berdasarkan pandangan ini, menurut Hassan, bunga bank adalah halal. Bunga bank tidak mempunyai sifat seperti riba yang berlaku pada zaman Jahiliyyah yang berlipat ganda dan eksploitatif (dzulm) tersebut. Bahkan lebih jauh lagi, dia memandang riba ada yang haram dan ada pula yang halal. Adapun riba fadl, dia cenderung menolaknya sebagai riba yang diharamkan. ${ }^{47}$

Sementara Shihab berusaha menguraikan persoalan riba secara komprehensif. Menurutnya, pembahasan secara singkat tentang riba yang diharamkan Alquran dapat dikemukakan dengan menganalisis

45 Adiwarman Karim, Bank Islam: Analisis Fiqh dan Keuangan, (Jakarta: IIIT Indonesia, 2003), hlm. 34-36.

46 Muslihun Muslim, Fiqh Ekonomi, (Mataram: LKIM, 2005), hlm. 151.

47 Jamal Abdul Aziz, Ahmad Hassan dan Pemikirannya tentang Riba, (Yogyakarta: Tesis Magister Agama, IAIN Sunan Kalijaga Yogyakarta, 2002), hlm. 3. 
kandungan ayat-ayat QS. Al Imran (3): 130 dan QS. Al-Baqarah (2): 278 atau lebih khusus lagi dengan memahami tiga kata kunci pada ayatayat tersebut, yaitu (1) adl'afan mudla'afah (2) ma baqiya min ar-riba, (3) falakum ru'us amwalikum la tadz̧limun wa la tudzlamun. Dari penelusuran terhadap tiga kata kunci tersebut, beliau berpendapat sebagai berikut:

"Kesimpulan yang diperoleh ini menjadi persoalan kata adl'afan mudla'afah tidak penting lagi, karena apakah ia syarat atau bukan, apakah yang dimaksud dengan pelipatgandaan atau bukan, pada akhirnya yang diharamkan adalah segala bentuk kelebihan. Namun kelebihan yang dimaksud adalah dalam kondisi yang sama seperti yang terjadi pada masa turunnya Alquran dan yang diisyaratkan oleh penutup ayat al-Baqarah 279 (la tadzlimun wala tudzlamun)". ${ }^{48}$

Pendapat tersebut diperkuat oleh kesimpulan akhir yang disusun oleh Shihab dengan mengatakan bahwa riba pada masa turunnya Alquran adalah kelebihan yang dipungut bersama jumlah utang yang mengandung unsur penganiayaan dan penindasan, bukan sekadar kelebihan atau penambahan jumlah utang. Meski tidak secara transparan menyebutkan tentang kehalalan bunga bank, dari kesimpulan tersebut dapat dipahami bahwa illat hukum yang dijadikan sandaran sama dengan kelompok ulama modernis.

Di sisi lain, Umar mencoba memberikan empat alasan mengapa

48 M. Quraish Shihab, Membumikan Alquran: Fungsi dan Peran Wahyu dalam Kehidupan Masyarakat, (Bandung: Mizan, 1999), 261-266. bunga bank itu tidak haram adalah sebagai berikut:

1. Jumlah bunga yang dipungut dan diberikan oleh bank kepada nasabah jauh lebih kecil dibandingkan dengan riba yang diperlakukan pada zaman Jahiliyyah.

2. Pemungutan bunga bank tidak akan membuat bank itu sendiri atau nasabahnya memperoleh keuntungan besar atau sebaliknya tidak akan merasa dirugikan dengan pemberian bunga.

3. Tujuan pengambilan kredit dari debitur pada zaman Jahiliyyah adalah untuk konsumsi, sementara sekarang dengan tujuan produktif.

4. Adanya kerelaan antara kedua pihak yang bertransaksi sebagaimana halnya kebolehan dalam jual beli dengan an taradhin. ${ }^{49}$

Perkembangan usaha Bank Syari'ah dan BPRS di Indonesia yang merupakan salah satu aplikasi dari hukum kontrak syari'ah hingga saat ini telah menunjukkan gambaran yang baik, terlihat semakin besarnya animo umat Islam untuk memanfaatkan layanan jasa perbankan syari'ah. Namun, bila dibandingkan dengan bank konvensional, perkembangan bank syari'ah hingga saat ini masih kurang menunjukkan pertumbuhan yang menggembirakan.

Mencermati pertumbuhan bank syari'ah yang tergolong lamban, pemakalah beranggapan bahwa salah satu faktor yang paling mendasar penyebab kelambanan perkembangan bank syari'ah di Indonesia adalah karena tidak adanya konsensus di antara para ulama dan cendekiawan

49 Umar Shihab, Hukum Islam dan Transformasi Pemikiran, (Semarang: Bina Utama, 1996), hlm. 127. 
Muslim tentang hukum bunga bank. Alasan logisnya adalah jika semua ulama dan cendekiawan Muslim sepakat tentang bunga bank sebagai riba dan dikeluarkannya dalam bentuk fatwa yang mengikat seluruh umat Islam, tentunya umat Islam akan mengalihkan investasinya pada perbankan syari'ah, sehingga lambat laun perbankan konvensional akan ditinggalkan oleh umat Islam.

Namun realitasnya, di Indonesia ini terdapat dua corak pemikiran tentang status bunga bank, yang agaknya perdebatannya tiada pernah berhenti. Meskipun, MUI telah mengeluarkan fatwa tentang haramnya bunga bank pada tanggal 16 Desember 2003 yang lalu, namun ternyata menimbulkan respon yang beragam di kalangan masyarakat, baik yang pro dan kontra. Oleh karena itu, wajar jika Saeed memasukkan faktor "upaya neo-Revivalisme dalam memahami hukum bunga bank sebagai riba dan penerimaan interpretasi tradisional tentang riba" sebagai faktor penting bagi tumbuhkembangnya bank Islam.

Perbedaan pendapat yang terjadi di kalangan ulama bukan disebabkan oleh faktor fanatisme, egoisme, atau hasrat untuk menonjolkan diri, melainkan sematamata didorong oleh keinginan yang kuat untuk mencari kebenaran berdasarkan kaidah dan prinsipprinsip yang telah ditetapkan. Oleh karena itu, mereka bersepakat dalam persoalan-persoalan yang memungkinkan untuk disepakati dan tetap berbeda pendapat dalam persoalan-persoalan yang terpaksa tidak dapat disepakati. Akhirnya, perbedaan pendapat itu adalah rahmat.

\section{Kesimpulan}

Prinsip/asas ibahah merupakan landasan pokok yang menjadi sumber dalam hukum kontrak syariah sedangkan asas lainnya merupakan pendukung dan melengkapi. Prinsip/asas kemaslahatan dan keadilan mempunyai kedudukan utama sebagai elaborasi dari asas ibabah karena nilai-nilai kemaslahatan dan keadilan merupakan ruh dan tujuan dalam setiap kontrak yang dibuat oleh para pihak.

Al-Quran dan hadist mengecam praktik riba dan mengharamkannya karena riba pada hakikatnya adalah pemaksaan suatu tambahan terhadap debitur untuk memikul segala risiko atas kerugian usaha, sementara kreditor bebas sama sekali dan harus mendapat persentase tertentu, sekalipun pada saat dananya mengalami kembalian negatif.

Larangan riba/bunga dalam kontrak merupakan perwujudan persamaan yang adil di antara pemilik harta (modal) dengan usaha, serta pemikulan resiko dan akibatnya secara berani dan penuh rasa tanggung jawab. Larangan tersebut sesuai dengan asas kemaslahatan dan keadilan, dimana didalamnya tidak memihak kepada salah satu pihak yang melaksanakan kontrak, melainkan keduanya berada pada posisi yang seimbang, ini mencerminkan asas keseimbangan sebagai salah satu asas perjanjian dalam hukum kontrak syariah.

\section{DAFTAR PUSTAKA}

A. Mas'adi, Ghufron, Fiqh Muamalah Kontekstual, Jakarta : PT. Raja Grafindo Persada, 2002.

Ali, Atabik dan Zuhdi Mukhdlor (Penyusun), Kamus Krapyak Al-'Asri: ArabIndonesia, Yogyakarta: Yayasan Ali Maksum Pondok Pesantren Krapyak, 1996.

Antonio, Muhammad Syafi'i, Bank Syari'ah: Dari Teori ke Praktik, Jakarta: Gema Insani Press,2001.

Bank Syari'ah

bagi Bankir dan Praktisi Kenangan, cet. I, Jakarta: Tazkia Institute, 1999. 
Anwar, Syamsul, Hukum Perjanjian Syariab: Studi tentang Teori Akad Dalam Fikih Muamalat, Jakarta: Raja Grafindo Persada,2007.

Kontemporer, Jakarta: RM Books.

$$
\text { Studi Hukum Islam }
$$

Arifin, Johan, Etika Bisnis Islami, Semarang: Walisongo Press, 2009.

Aziz, Jamal Abdul, Ahmad Hassan dan Pemikirannya tentang Riba, Yogyakarta: Tesis Magister Agama, IAIN Sunan Kalijaga Yogyakarta, 2002.

Basyir, Ahmad Azhar, Hukum Islam tentang Riba, Utang-Piutang, Gadai, Bandung: PT Ma'rif, 1983.

Budiono, Herlien, Asas Keseimbangan Bagi Hukum Perjanjian Indonesia, Bandung: Citra Aditya Bakti, 2006.

Jamil, Fathurrahman et.al., Hukum Perjanjian Syariah dalam Kompilasi Hukum Perikatan, Bandung: Citra Adutya Bakti.

Karim, Adiwarman, Bank Islam: Analisis Figh dan Keuangan, Jakarta: RajaGrafindo Persada, 2007.

Khairandy, Ridwan, "Landasan Filosofis Kekuatan Mengikatnya Kontrak", dalam Jumal Hukum, Edisi Khusus Vol. 18 Oktober 2011.

M. Taufiq, Muklisin Purnomo, Model Pemberdayaan Aset Wakaf Masjid Secara Produktif di Masjid Jogokariyan Yogyakarta, Perada: Jurnal Studi Islam Kawasan Kemelayuan, Vol.1, No.2, 2018.

Mannan, Muhammad Abdul, Islamic Economic, Theory and Practice, terj. Nastangin, Yogyakarta : Dana Bhakti Wakaf, 1997)

Minhaji, Akh..,dkk, Antologi Hukum Islam: Pps prodi HI Pasca, Yogyakarta: Sukses Offset, 2010.

Muhamad, Teknik Perbitungan Bagi Hasil dan Profit Margin pada bank Syari'ab, Yogyakarta: UII Press, 2001.

Muslim, Muslihun, Figh Ekonomi, Mataram: LKIM, 2005.

Nurjihad, Jurnal Hukum IUS QUIA IUSTUM NO. 3 VOL. 20 JULI 2013.

Rahmawati, Anita, Riba Dalam Perspektif Keuangan Islam, hlm. 5-6, dalam http://p3m.stainkudus.ac.id/files/ Anita.pdf di akses tanggal 15 Oktober 2018 jam 14.00 WIB.

Rivai, Veithzal, et.al, Bank and Financial Institution Manajement Conventionaland
Sharia System, Jakarta: RajaGrafindo Persada, 2007.

S.Sewu, P. Lindawaty, Aspek Hukum Perjanjian Baku dan Posisi Berimbang Para Pihak Dalam Perjanjian Waralaba, Bandung: Disertasi Program Doktor Ilmu Hukum Program Pascasarjana Universitas Katolik Parahyangan, 2007.

Sabiq, Sayyid, Fikih Sunnah 12, cet.I, Bandung: PT. Al-Ma'rif, 1987.

Saeed, Abdullah, Islamic Banking and Interest, A Study of Probibition of Riba and its Contemporary Interpretation, Leiden: E.J. Brill, 1996.

Shihab, M. Quraish, Membumikan Alquran: Fungsi dan Peran Wabyu dalam Kehidupan Masyarakat, Bandung: Mizan, 1999.

Shihab, Umar, Hukum Islam dan Transformasi Pemikiran, Semarang: Bina Utama, 1996.

Subekti, Hukum Perjanjian, Jakarta: Intermasa, 1984.

Tim Pengembangan Syari'ah Institut Bankir Indonesia, Konsep, Produk dan Implementasi Operasional Bank Syari'ah, (Jakarta: Djambatan, 2002), hlm. 39-40.

Wirdyaningsih, et.al, Bank dan Asuransi Islam di Indonesia, ( Jakarta: Kencana, 2005. 